\title{
Towards Strategic Plan for Wide Spreading of Solar Water Heaters in Libya
}

\author{
M.J.R. Abdunnabi ${ }^{1}$, and M. A. Musa ${ }^{2}$ \\ ${ }^{1}$ Center for Solar Energy Research and Studies, Tajura, P.O. Box 12932 Tripoli \\ e-mail: Abdunnabi@CSERS.ly
}

${ }^{2}$ Libyan Atomic Energy Establishment

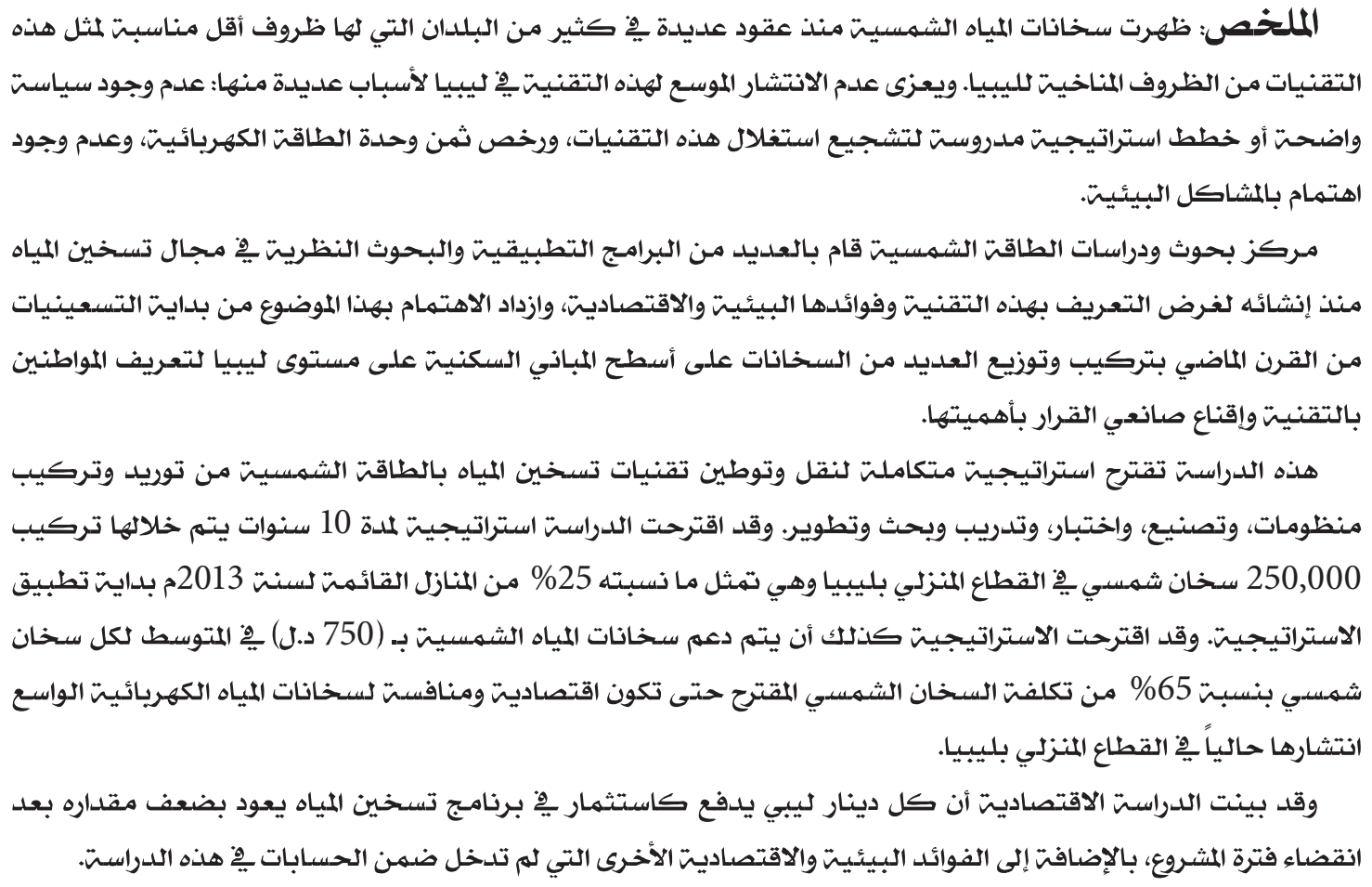

Abstract: Solar water heaters have been in use for decades in many countries in the world that have less favorable climatic conditions for solar energy as compared with Libya. However, still there is no usage of such technologies in the country. This could be attributed to many factors including, among others, lack of clear policy and/or serious plans to establish such technology, cheap prices of conventional energy, and lack of environmental awareness. 
The Center for Solar Energy Research and Studies (CSERS) of Libya has developed an excellent research and development program on national scale for domestic solar water heating systems. The national program started in the early 1990's aiming at increasing public awareness. The program utilizes different ways such as pilot projects, studies, workshops, and reports to convince people and decision- makers of Libya about this subject and its benefits.

This paper attempts to suggest a strategic plan (win-win situation between government and people) for encouraging and helping wide spread (replacement) of solar water heaters nationwide based on economic and environmental pointers in favour of the replacement.

The suggested strategic plan is to provide $25 \%$ of existing houses in 2013 with solar water heating systems by 2022, with governmental subsidy of up to $65 \%$ of the system cost. The study has shown that every L.D. paid by the government will return with at least 2 L.D. after 10 years of investment without considering the money saved from the fuel savings, power plant installations to fulfill the demand, and the environmental benefits.

Keywords: Solar water heaters, Wide-spread implementation, Strategic plan

\section{INTRODUCTION}

Solar water heaters are devices used to provide hot water at temperature less than $80^{\circ} \mathrm{C}$ in applications such as residential, commercial and service buildings. Currently, these systems are available in the market in different technologies and configurations and can be designed to suit every application. It is a maturely proven technology for over 40 years of experience, and can provide over $80 \%$ of the hot water requirements if it is well designed.

Recently it is becoming obvious that using solar water heating technology in providing hot water to domestic buildings is very economical in many regions in the world. Yet, there are many factors affecting people's acceptance of this technology, such as: the prices of the conventional energy, the prevailing weather conditions in the region, the governmental policies and programs towards the renewable energy technologies and their wide spread implementation, and the public awareness of the environmental issues. Such factors are very important in putting any plan for promoting solar water heaters technology and must be considered.

The Center for Solar Energy Research and Studies (CSERS) of Libya has developed an excellent research and development program on national scale for domestic solar water heating systems. The national program started in the early 1980's aiming at increasing public awareness. The program utilizes different ways such as pilot projects, studies, workshops, and reports to convince the public and decision- makers of Libya about this subject and its benefits.

The program will culminate with the demonstration of solar water heating systems subjected to actual working conditions and by using different 
technologies and construction materials (closed and open systems, evacuated tubes and flat plate collectors, copper, galvanized steel, aluminum, absorber plates and tubes, selective coating and black paint). The program is designed to align technical knowhow with the ultimate goal of developing a local manufacturing base for the solar water heating systems. The program is also aiming at generating data necessary to the commercialization phase. The expected results will respond to local needs, national strategies and regional objectives.

More than 100 systems installed in different houses were closely monitored through a field study carried out by CSERS, and have shown that the contribution of solar water heating in the residential sector can be more than $70 \%$ of hot water demand in domestic sector, which is very encouraging result [1]. To put this into perspective, according to the data obtained from GECOL, the domestic water heating accounts for $29.82 \%$ of the energy consumed in the residential sector and $9.9 \%$ of the total national electricity consumption. These figures urge the importance of establishing a national strategic plan to replace electric water heaters (commonly used) with technically mature and economically feasible solar water heaters in the domestic and services sectors in Libya.

Most countries that succeeded to create sustainable market of solar water heaters have implemented accurate (concrete) plans to support the diffusion of these technologies. These plans are vary from country to country according to the economic status, public awareness, conventional energy prices, people standard of Living, etc.

Tunisia for instance, has implemented a program labeled PROSOL to help widespread SWH in the domestic and commercial sectors. The program is based on giving a subsidy for the qualified systems of about $20 \%$ of the capital cost of the system, and the remaining price is considered as a 5 year term loan and will be harnessed through the electric utility by adding a certain amount of money in the electricity bill of the beneficiary. In fact, the amount added is more or less equivalent to the monthly savings of SWH system, which means that the beneficiary will not be affected (financially) by installing the system. This program by far encourages people to install SWH systems, and hence, over 85,000 systems were installed within three years, and the number of suppliers increased from 3 in 2005 to 40 in 2009 [2].

Many studies [1,3] were conducted to suggest strategic plans for wide spreading the use of solar water heaters in Libya. These studies were based on economic and social pointers at that time, and may not be applicable nowadays.

This paper seeks to find a suitable strategic plan for spreading this technology in the domestic sector in Libya. The strategy is mainly based on the possibility of utilizing the current subsidy of electricity to subsidise SWHs program.

\section{WATER HEATING IN THE DOMESTIC SECTOR}

According to the annual report of General 
Electric Company of Libya (GECOL) 2009 [4], domestic sector consumes $33.24 \%$ of the total electricity sold to different sectors in Libya as shown in Figure 1. In the meantime, according to a study conducted by Khalat et al. [5], water heating in the domestic sector was the biggest consumer representing about $30 \%$ of the total electricity consumed in the domestic sector of Libya as shown in Figure 2. In total, water heating for domestic purposes represents around 9.9\% of the total electricity distributed all over Libya. The total electric energy produced in 2009 was about $30,373 \mathrm{GWh}$, and the amount of electricity sold was about 19,266 GWh. Therefore the annual electricity used for domestic hot water was around 3010GWh.

The available data have been taken as the base to estimate the energy used for water heating in residential sector. Two sources of data were used in the estimation process. The first source (first approach) of data were obtained from GECOL, and General Authority for Information (GAI), whereas the second source (second approach) of data was based on field tests. The following sections will go through these approaches in detail.

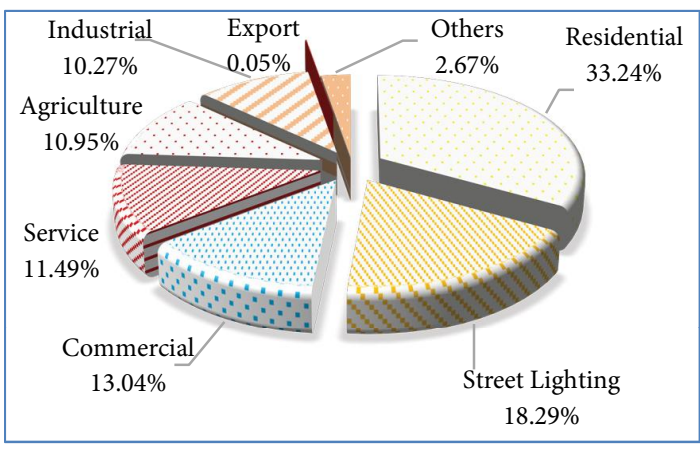

Figure (1). Sectarian distribution of electricity in Libya, 2009

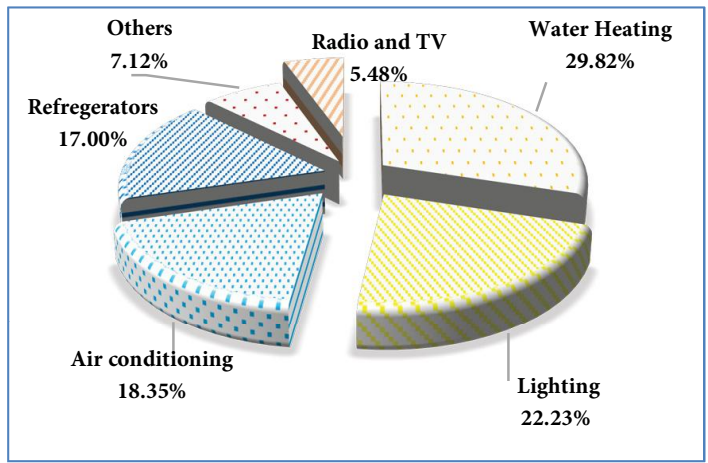

Figure (2). Electricity distribution in the Libyan houses

\subsection{Hot Water Demand Estimation}

The data obtained from GECOL and GAI are listed in Table 1 to estimate the energy consumed for water heating per family.

From Table 1 we can calculate the maximum possible energy consumption per family based on the electricity generated:

$$
\mathrm{WH}_{\max }=\frac{\text { Electric Energy Production } \times \% \text { of Water Heating }}{\text { Number of Houses }}
$$$$
=\frac{30,373,000,000 \times 0.099}{902,965}
$$

$=3330 \mathrm{kWh}$ 
Table (1). Various data from GECOL and GAI

\begin{tabular}{|c|c|c|c|}
\hline No & Category & Value & Remark \\
\hline 1 & $\begin{array}{l}\text { Electric } \\
\text { Energy } \\
\text { production }\end{array}$ & $\begin{array}{l}30,373 \\
\text { GWh }\end{array}$ & $\begin{array}{l}\text { GECOL } \\
(2009)\end{array}$ \\
\hline 2 & $\begin{array}{l}\text { Electric } \\
\text { Energy Sold }\end{array}$ & $\begin{array}{l}19,266 \\
\text { GWh }\end{array}$ & $\begin{array}{l}\text { GECOL } \\
(2009)\end{array}$ \\
\hline 3 & $\begin{array}{l}\text { Percentage } \\
\text { of electricity } \\
\text { used for } \\
\text { water heating } \\
\text { in domestic } \\
\text { sector }\end{array}$ & $9.9 \%$ & $\begin{array}{l}33.24 \% \\
\times \\
29.82 \%\end{array}$ \\
\hline 4 & $\begin{array}{l}\text { Number of } \\
\text { houses (2009) }\end{array}$ & 902,965 & \\
\hline 5 & $\begin{array}{l}\text { Average } \\
\text { family }\end{array}$ & 6 & $\begin{array}{l}\text { GAI, } \\
2007\end{array}$ \\
\hline
\end{tabular}

Whereas, the minimum energy consumed in average per family can be calculated as above based on electricity sold:

The second approach used to estimate the electric energy consumption per Libyan family was through the use of field test data of solar water heaters for a whole year $[1,6]$.

$\mathrm{WH}_{\min }=2108 \mathrm{kWh}$

From these data, the energy consumed for water heating per capita was obtained which was about $455.13 \mathrm{kWh} /$ person, and using the average Libyan families as given in Table 1 , the energy consumed for water heating per family can be found:

Actually, none of the above results can be considered an accurate representation of the energy consumed for water heating per family. This is due to the fact that, getting $\mathrm{WH}_{\text {measured }}=455.13 \times 6=2731 \mathrm{kWh} \ldots$ (3) accurate results requires a lot of work and facilities which are beyond the scope of this work. The value of $\mathrm{WH}_{\max }$ is considered too high because we used the percentage of electric energy used for residential water heating deduced from electricity generated. Whereas as the value of $\mathrm{WH}_{\text {min }}$ is considered a bit low as there still over 10,000 GWh of electricity generated and not accounted for as electricity sold. The last value $\mathrm{WH}_{\text {measured }}$ is not very accurate also because the number of samples taken was very small.

However, in this study we considered as a representative value of the energy consumption for water heating per family just because this value lies between the maximum and minimum values, and it is obtained from measured data.

\section{POTENTIAL OF SOLAR WATER HEATERS IN LIBYA}

There are about 140 million $\mathrm{m}^{2}$ of solar thermal collector's area in operation all over the world, and they only represent $2.3 \%$ of the world potential [7]. Prior to establishing any plan it is very important to know its technical, economical, and market potential. Many studies were conducted to estimate the potential of solar water heaters [8-11]. For instance, Pillai and Banerjee [8] have estimated the potential of solar water heaters in a targeted area in India by simulating it through TRNSYS taking micro-level factors. The study has found that the technical potential of the targeted area $\left(2 \mathrm{~km}^{2}, 10,000\right.$ inhabitants) is about $1700 \mathrm{~m}^{2}$. In this section, the technical potential of solar water heaters in Libya is sought. 
There are many factors affecting the estimation of the technical potential of solar water heaters in the domestic sector in general. Some of the important factors are: weather conditions, suitability of the houses, conversion efficiency of the technology used, etc.

The main important factors considered in this study are the solar radiation availability all over the country, the suitability of the existing houses to install such systems, and the conversion efficiency of the systems. According to the statistical figures of the General Authority for Information, 2007 [12] the types of houses in Libya are shown in Figure 3.

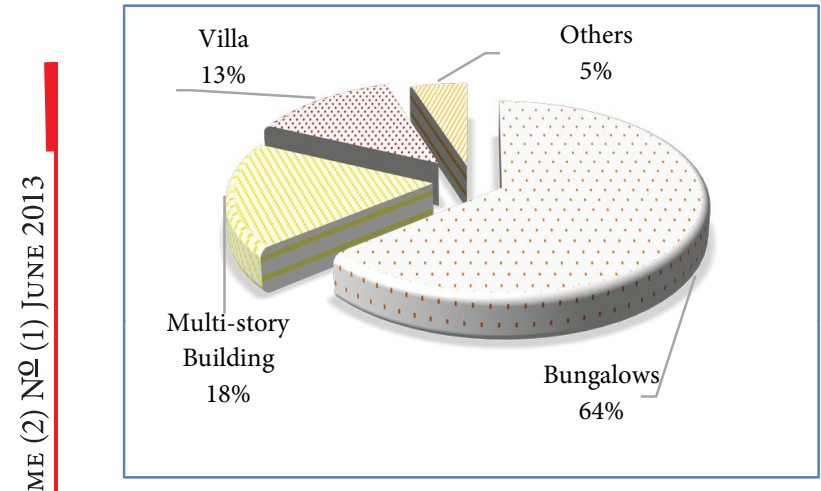

Figure (3). The share of the existing types of Libyan houses

From Figure 3 it can be considered that the building characteristics of vast majority of Bungalow and Villa houses and some of multi-story buildings are suitable for the installation of solar water heaters, and therefore it can be considered that $75 \%$ of houses in Libya are suitable for the installation. Table 2 lists the factors considered for evaluating the technical potential of solar water heaters in Libya.

Using the information listed in Table 2, the estimated technical potential of SWHs in domestic sector can be found by using the following correlation:

$A_{c}=\frac{Q_{d}}{\eta G_{t}}(\%$ of SF $)(\%$ of eligible houses $)$.

Where

$\mathrm{A}_{\mathrm{c}}$ Collector areas potential

$Q_{d}$ Total hot water energy demand

$G_{t}$ Solar radiation on collector area

$\eta$ Average conversion efficiency

$$
\begin{aligned}
A_{c} & =\frac{2731 \times 902,965}{0.3 \times 1930} \times 0.72 \times 0.75 \\
& =2.3 \text { Million sq. } \mathrm{m}
\end{aligned}
$$

Table (2). Data used to estimate the technical potential of SWH systems

\begin{tabular}{|c|l|c|}
\hline No & \multicolumn{1}{|c|}{ Item } & Value \\
\hline 1 & Number of houses & 902,965 \\
\hline 2 & Suitable houses & $75 \%$ \\
\hline 3 & Average family size & 6 \\
\hline 4 & $\begin{array}{l}\text { Hot water } \\
\text { consumption per } \\
\text { house }\end{array}$ & $\begin{array}{c}2731 \\
\mathrm{kWh} / \text { year }\end{array}$ \\
\hline 5 & $\begin{array}{l}\text { Average solar } \\
\text { radiation }\end{array}$ & $\begin{array}{l}1930 \\
\mathrm{kWh} / \mathrm{m}^{2} / \text { year }\end{array}$ \\
\hline 6 & $\begin{array}{l}\text { Average solar } \\
\text { fraction }(\mathrm{SF})\end{array}$ & $32 \%$ \\
\hline 7 & $\begin{array}{l}\text { Conversion } \\
\text { efficiency }(\eta)\end{array}$ \\
\hline
\end{tabular}

This means that technically there is a potential in Libya to install over 2.3 million square meters of collector areas for heating water in the residential sector only according to data of 2009.

\section{PROGRAM OF WIDESPREADING SOLAR WATER HEATERS}

As mentioned in the previous section, solar water heaters cannot be competitive 
to electric water heaters under the current economic pointers. Therefore, convenient sustainable plan should be implemented to urge and encourage people to install solar water heaters instead of electric ones. The complete strategic plan suggested in this study includes: feasibility analysis, installation scheme, financing scheme (incentives and loans), systems testing and certifications, manufacturing, research and development, and training. This strategy should be frequently revised and updated.

\subsection{Feasibility Study}

The cost of solar water heaters in the market today varies considerably according to quality and technology. From the very recent importation records of the CSERS and REOAL, the average costs of solar water heaters (good quality flat plate collectors) are as follows:

- 200 liters with over $3 \mathrm{~m}^{2}$ is about 960

\section{L.D}

- 300 liters with over $4 \mathrm{~m}^{2}$ is about 1340

\section{L.D}

The cost of solar water heaters considered in this study is the average of the above costs and is equal to 1150 L.D.

In the meantime, only electrical water heaters are used in Libya (no gas or other heaters used) and the cost of such system in local market varies from 100 L.D. to 125 L.D. for 80 liters depending on the quality of the system. Therefore, in this study the cost of electric water heaters is taken as the average of the aforementioned values and is equal to 112.5 L.D. Table 3 illustrates the assumed figures considered in this study.
Table (3). Summary of different water heater prices and some economic indexes

\begin{tabular}{|c|l|c|c|}
\hline No & Category & Value & $\begin{array}{l}\text { Lifetime } \\
\text { (year) }\end{array}$ \\
\hline 1 & $\begin{array}{l}\text { Solar water } \\
\text { heaters (L.D.) }\end{array}$ & 1150 & 10 \\
\hline 2 & $\begin{array}{l}\text { Electric water } \\
\text { heaters (L.D.) }\end{array}$ & 112.5 & 7 \\
\hline 3 & $\begin{array}{l}\text { Interest rate } \\
\text { (\%) }\end{array}$ & 0 & \\
\hline 4 & $\begin{array}{l}\text { Electricity } \\
\text { (L.D./kWh) }\end{array}$ & 0.02 & \\
\hline
\end{tabular}

The interest rate is considered zero in this study as the subsidy and loans that will be given are obtained from savings of oil and electric subsidy used in water heating for residential sector, in addition this will encourage the vast majority of people to be involved in the program.

\subsubsection{Feasibility from the public point of View}

To make a sustainable market for solar water heaters, they have to be seen by the public economically feasible. The economic analysis of the conventional and solar water heaters is obtained and the summary is given in this section as shown in Table 4.

The economic analysis conducted in this study is based on 10 years (lifetime of SWHs) and therefore, the capital cost of the electric heaters is calculated over 10 years. In addition, most Libyan houses are provided with two or more electric heaters, and hence the capital cost is considered to include the cost of two electric water heaters over 10 years.

The operating cost in Table 4 is 
calculated as the cost of electricity used to cover hot water demand. In case of solar water heaters, the system will provide only $72 \%$ of the demand from the sun and the remaining which is $28 \%$ will be provided from electricity. The maintenance cost is considered as $5 \%$ of the capital cost, and the electricity price is considered to be frozen over 10 years at $0.02 \mathrm{LD} / \mathrm{kWh}$. For further clarification, the numbers in Table 4 are presented in Figure 4.

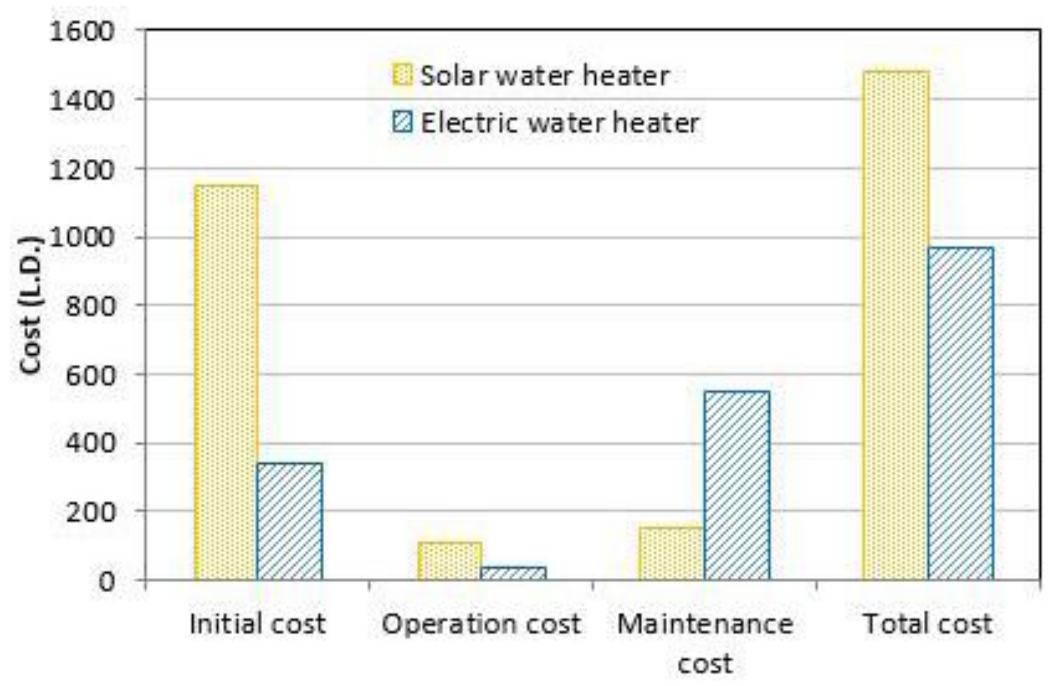

Figure (4). Costs of solar and electric water heaters over 10 years

Table4: Economic analysis of solar and electric heaters over 10 year period

\begin{tabular}{|l|l|c|c|}
\hline No & Category & $\begin{array}{l}\text { Solar } \\
\text { water } \\
\text { heater }\end{array}$ & $\begin{array}{l}\text { Electric } \\
\text { water } \\
\text { heater }\end{array}$ \\
\hline 1 & Capital cost & 1150 & 321 \\
\hline 2 & $\begin{array}{l}\text { Installation } \\
\text { cost }\end{array}$ & 110 & 40 \\
\hline 3 & $\begin{array}{l}\text { Operation } \\
\text { cost }\end{array}$ & 153 & 546 \\
\hline 4 & $\begin{array}{l}\text { Maintenance } \\
\text { cost }\end{array}$ & 71 & 45 \\
\hline 5 & Total cost & 1484 & 952 \\
\hline
\end{tabular}

It is clear from the economic analysis over 10 years of water heaters as shown Figure 4, that solar water heaters are still not very competitive to electric water heaters, and therefore it is not expected that people will positively look at this technology unless convenient strategic plan to make these systems more competitive is implemented.

\subsubsection{Feasibility from the Government Point of View}

As we have seen from the previous section solar water heaters will never attract peoples interest as long as it remains very expensive compared to the other alternatives. In addition, are always taken into account up-front cost more than the operational cost which is also a big issue and need to be changed as we seek to spread the use of solar energy instead of the pollutant old technology.

The role of the government is very important in such transient stage; the 
government has to take responsibility of securing energy supply and preserving the environment for the current and future generations. In this context, the government has to consider the following points:

1. Preserving the environment from great amount of $\mathrm{CO}_{2}$ emissions

2. Contribution to alleviate the ever increasing demand of electricity

3. Energy security through diverting energy sources

4. Oil savings to be exported (additional source of revenue).

In our case, as we subsidy the conventional energy the benefit from the replacement will be huge, because the government will save the subsidy and the oil used to produce electricity for residential water heating. The next sections attempt to articulate a strategic plan for the solar water heaters spreading.

\subsection{Installation Scheme}

In a 10 year scenario starting 2013 suggested in this study, 250,000 homes are targeted for the installation of solar water heaters. This represents around $25 \%$ of the expected total number of houses in 2013 represent over $21 \%$ of the houses in 2022.

It is assumed that each house will have one solar water heater only (size of the system might vary). The first year installation will start with a small number compared to the successive years where the accumulated experience and people awareness help the wide spread use of this technology. The logistic function (5) with the appropriate values is used to define the expected installation scheme for the mentioned period.

$$
y(t)=\frac{A}{1+\exp \left(-b\left(t-t_{m}\right)\right)}
$$

Where:

$y(t)$ The number of the solar systems to be installed per year.

A Maximum number of systems to be installed per year.

b The diffusion rate

t Year $\mathrm{t}$

$\mathrm{t}_{\mathrm{m}} \quad$ The time (in years) at which the curve reaches half the asymptote value (A), i.e. where the derivative of the curve is at a maximum.

The parameters used in considering realistic diffusion trends were selected to insure realistic and practical action plan. This function starts at low penetration rates to allow time for the infrastructure development and, then, the penetration rate goes up as the market becomes more mature.

The logistic function fits in well with gradual building of capacity and experience. The shape of the logistic function which defines the rate at which plants are installed can be influenced by policies that accelerate market transformation. Figure 5 demonstrates the trend of this logistic function. The installation starts with relatively small number (less than 3700 systems for the first year) to be increased through the subsequent years with over 43,000 systems in the last year of the plan.

\subsection{Financing Scheme}

Due to the high up-front cost of solar 
water heaters compared to alternative types of heaters, subsidies are recognized as an important issue to help introduce SWHs (as new technology) by lowering their cost and shortening their payback period.

However, past experience claimed that heavy subsidy will never make sustainable market and hence the program will fail. Therefore, subsidy has to be somehow reasonable to make the price of solar water heaters competitive with the common used electric water heaters.

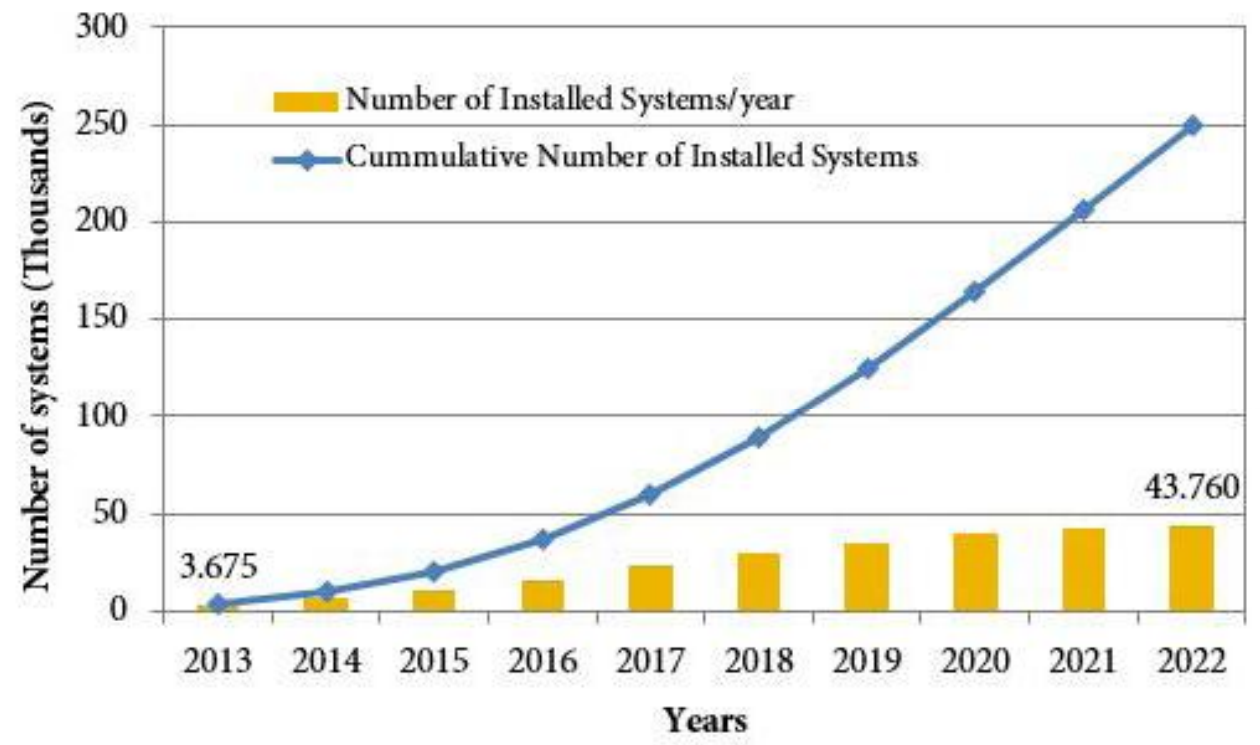

Figure (5). Installation scheme for the 10 year plan

\subsubsection{Subsidy Resources}

The electricity in Libya is heavily subsidized to become affordable according to the peoples standard of living. This, of course, will help stabilize the market and stimulate the economic activities in the country. Due to the current political and economic situation of the country, it is not advisable to increase the electricity prices just to make solar water heaters more competitive; however, there are many other ways of savings that can be implemented successfully such as using wise energy policies, energy saving equipments and renewable energy technology when it is possible.

In this context, the study has suggested a method of financing that benefits from the money used for subsidizing the electricity used for water heating in domestic sector only, and also we will benefit from the oil savings that would otherwise be used for heating water in residential sector. This money can be used as a subsidy of SWHs program.

In this scheme, it is suggested to benefit from the subsidy of the electricity cost which estimated about $0.082 \mathrm{~L} . \mathrm{D} / \mathrm{kWh}$, (the actual electricity cost is over $0.102 \mathrm{~L} . \mathrm{D} / \mathrm{kWh}$ [13], whereas the subsidized prices for domestic sector is 0.02 L.D./kWh). This money will be used to subsidies the replacement program in the strategy. 
Based on the actual electricity prices (0.102 L.D./kWh), of 2009 the money going for domestic water heating can be estimated at over 251.5 million Libyan dinars, whereas the expected money to be paid in 2013 for domestic water heating according to 2009 statistics is about 273 million Libyan dinars, and will be over 328 million Libyan dinars in 2022. The accumulated money paid for domestic water heating in the 10 year period is estimated to be about 3 billion Libyan dinars, which is a very huge amount of money to be paid for water heating in a country such as Libya that has a huge potential of solar energy.

Over the ten year time plan suggested the total subsidy ( $0.082 \mathrm{~L} . \mathrm{D} / \mathrm{kWh}$ ) for water heating can be estimated as 2.4 billion Libyan dinars. According to the installation scheme suggested in this study over ten years, the aggregate savings can be estimated as (taking into account that solar systems can provide only $72 \%$ of the demand) 1.55 billion Libyan

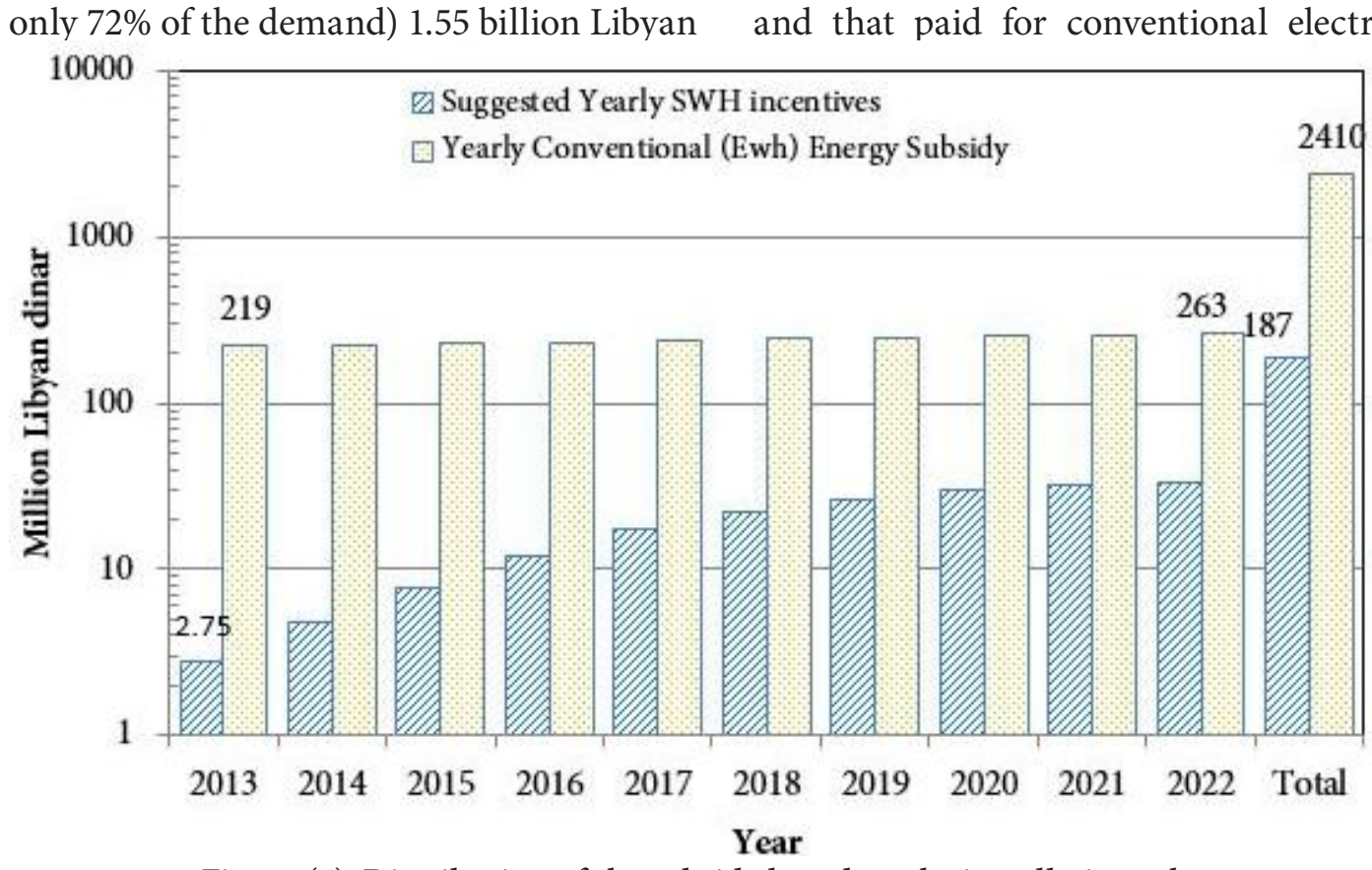

Figure (6). Distribution of the subsidy based on the installation scheme dinars. Some of this money can be used to subsidies solar water heaters program (250,000 SWHs).

In this scenario plan it is suggested to subsidies (as an incentive) on average each system with 750 L.D. which actually represent over $65 \%$ of the system cost. This will make these systems very competitive to electric water heaters and hence will encourage people to turn to solar water heaters.

Figure 6 shows the expected money saved and paid due to the replacement of electric water heaters with solar water heaters, at the end of the program (at year 10) the total amount of money paid as incentives is equal to 187.5 Million L.D. whereas, the expected yearly money paid as a subsidy of electricity used for domestic water heaters is equal to 2.4 billion Libyan Dinars. Figure 7 shows the yearly percentage of the money paid as subsidies to solar water heating program and that paid for conventional electricity 
used for domestic water heating. It is clear that, the maximum yearly percentage is less than $13 \%$ which is very small and very encouraging.

In fact, the good quality systems lifetime is over 10 years, which means that the energy saving will continue for further 10 years up to 2031 (considering systems installed in the last year, year 10, in the scenario) as shown in Figure 8. The money paid and saved from this program is shown in Figure 9.

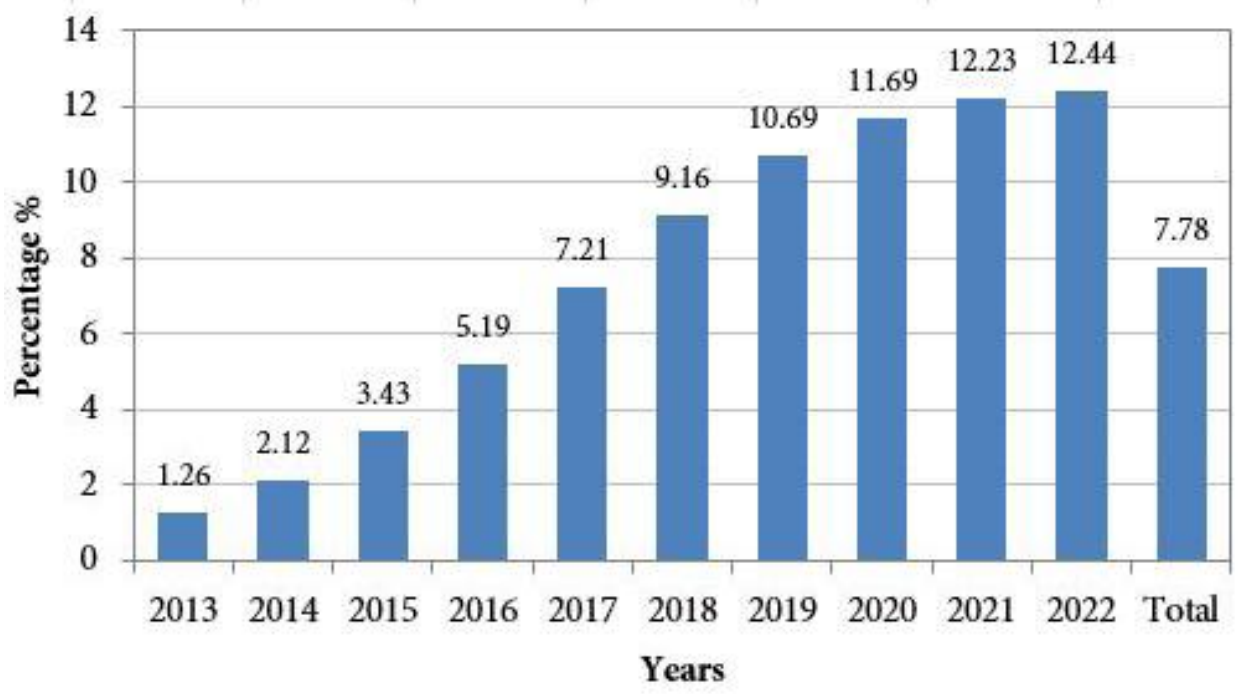

Figure (7). Percentage of money paid as subsidy for solar and electric water heaters

It can be seen from Figure 9 that the total savings along the lifetime of the solar systems installed in this program are over 403 million Libyan dinars, and the total subsidy given by the government to this program is only equal to 187.5 million Libyan dinars with net profit (otherwise will be given as a subsidy) of 215.8 Million Libyan dinars. This means that every one Libyan dinar paid by the government as a subsidy to the solar water heaters program will return after less than the lifetime of the system with over 2 times. Hence, it can be considered as a profitable investment. All that without considering the cost of installing electric power plants to cover the demand that would otherwise require a plant with a capacity of $56 \mathrm{MW}$, and if we consider the load factor (0.65) then the nominal capacity of such plant would be $100 \mathrm{MW}$, the cost of such plant in Libya is about 94.8 million US dollars. In addition to the fuel savings to be exported, and the huge environmental benefits.

Figure 10 shows the money cash flow of the solar water heaters program. The maximum yearly money paid by the government for the program is about 12.6 million Libyan Dinars in the sixth year of the program (year 2018). The total actual money paid during the 10 year installation program in case of subtracting the savings is around 72.7 million Libyan dinars. 


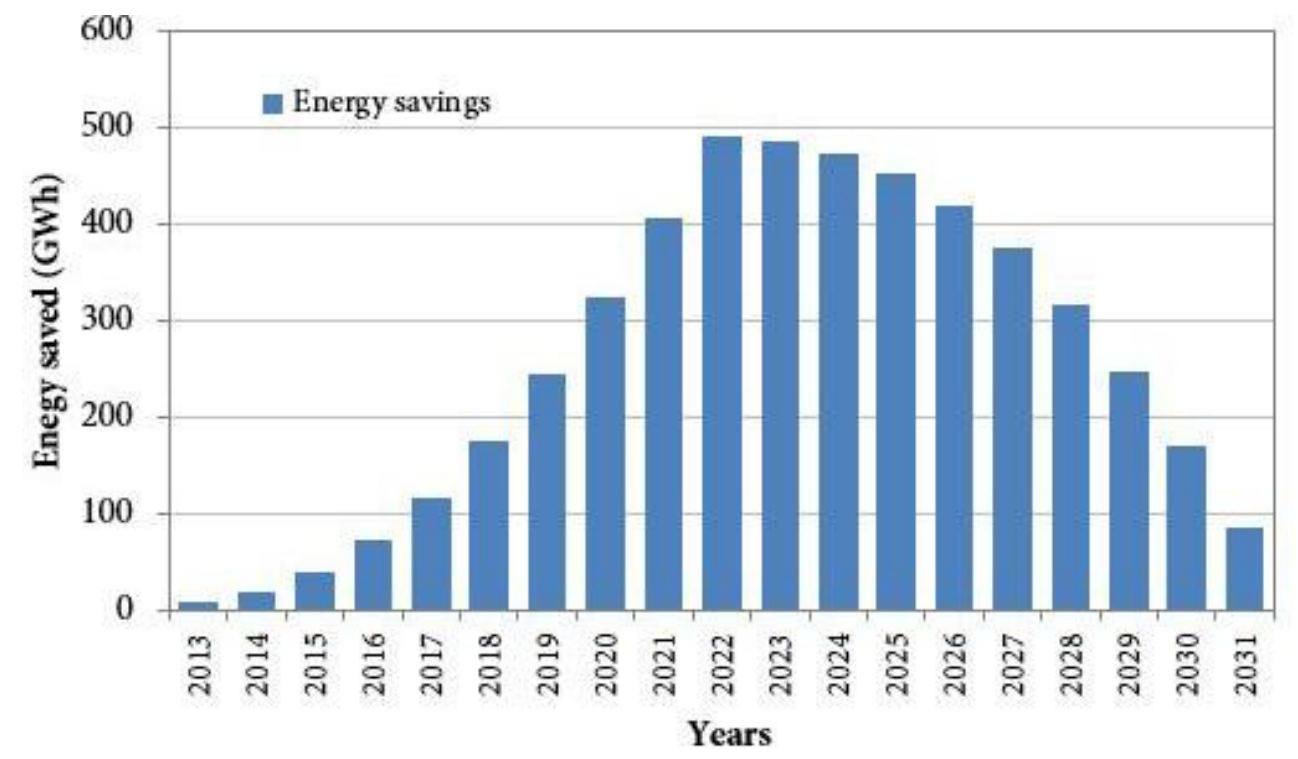

Figure (8). Energy savings of the systems along their lifetime

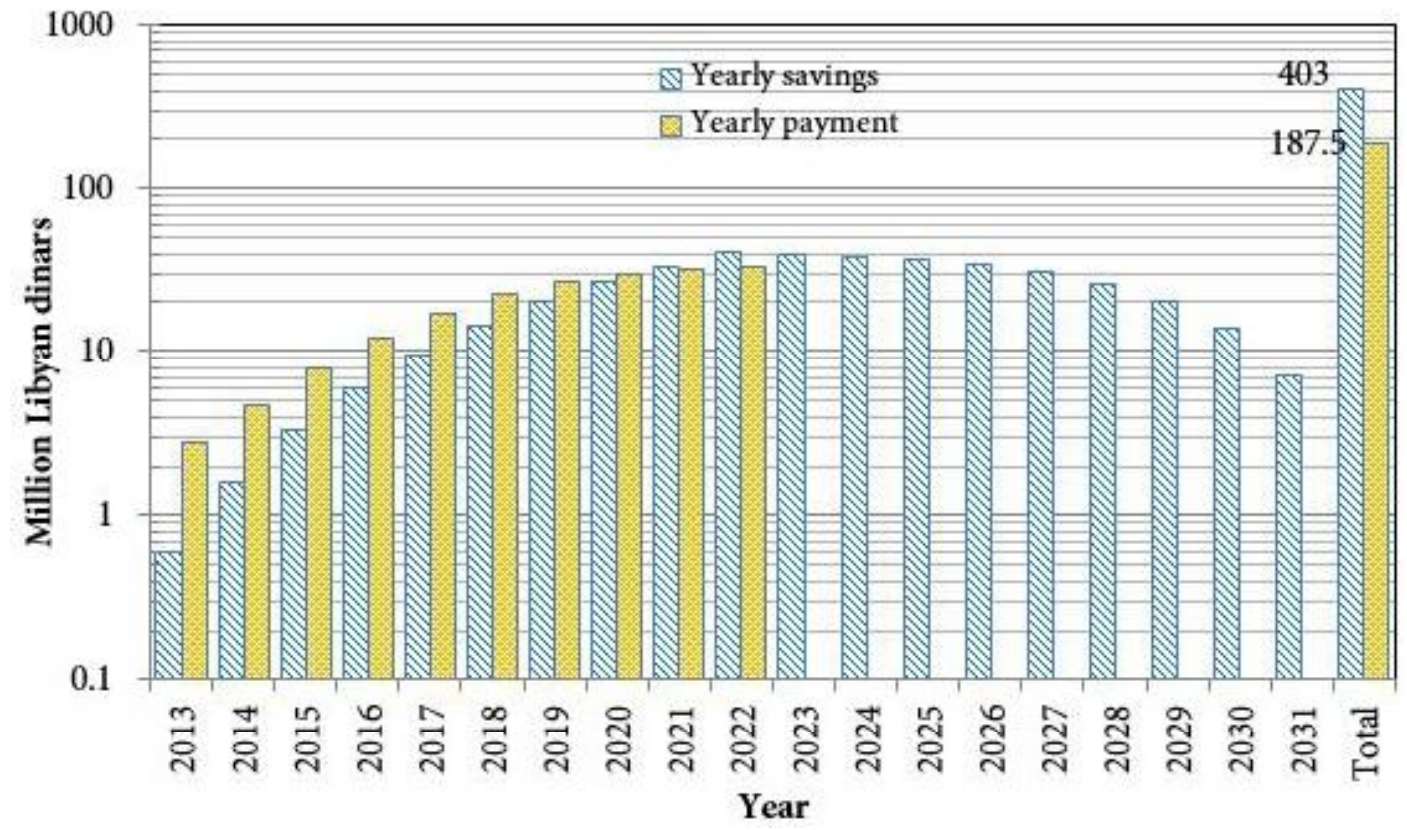

Figure (9). Yearly savings according to the installation scheme

\subsection{Testing and Certification}

To guarantee the success of the program, the quality of systems should be controlled, and the eligible systems for funds should be those that have approved certificate of quality. In this manner, the market will be protected from bad quality systems. The
CSERS has the capability of testing and issuing certificates to all types of solar water heaters available in the market today, and therefore, it is very important to mandate the CSERS to carry out this job to guarantee the quality and the eligibility of subsidy. 


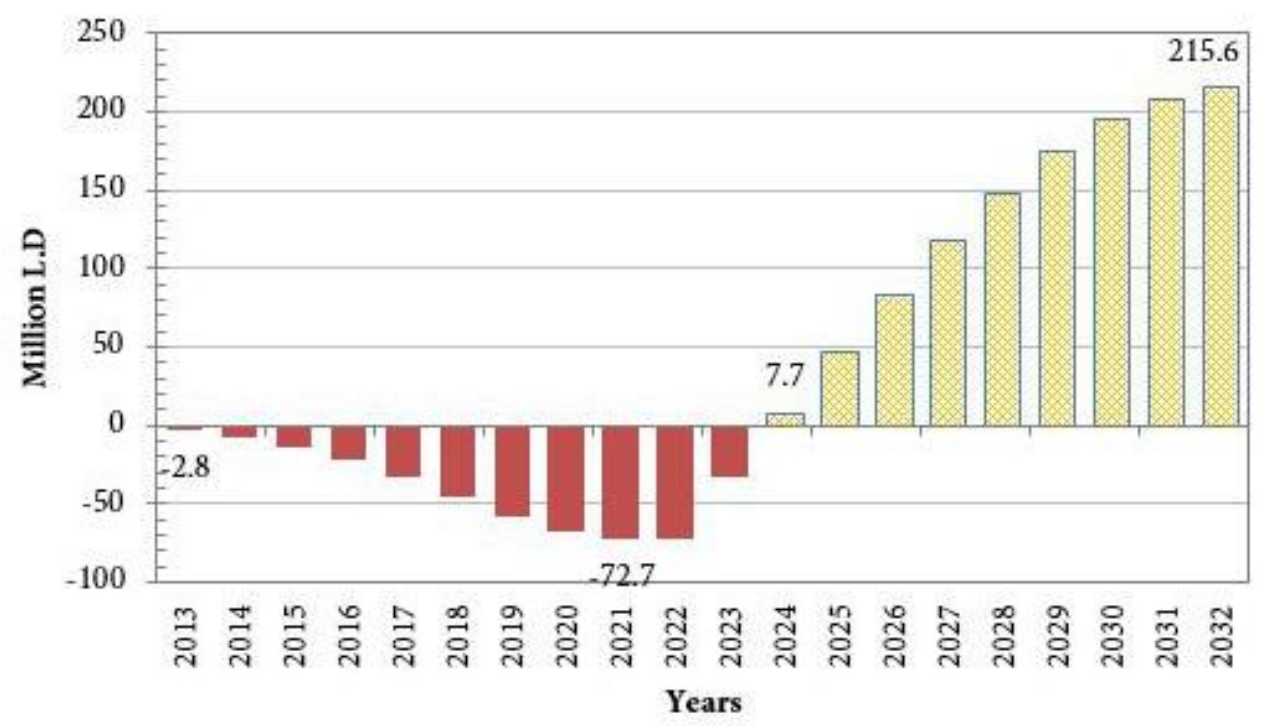

Figure (10). Money cash flow of the solar water heaters program

\subsection{Manufacturing}

Due to the massive number of systems to be installed over the coming years, local manufacturing has a lot of merits such as creating new jobs, using local materials, enhancing research and development activities, and of course reducing the cost of the systems. The strategy suggested for manufacturing is to start after the end of the second year (about 10,000 systems installed) where the technology becomes more popular among many people, and also the installation potential and the suitable technology to the Libyan environment will become more obvious.

\subsection{Research and Development}

Of courses, this kind of technology depends strongly on the environment, operating conditions, and the available material to be used for system manufacturing. Therefore, there is a lot of room for research and development to find the optimum design suitable for Libyan environment.
This job is the main role of the CSERS and should be enhanced.

\subsection{Training}

Due to the large number of systems to be installed each year, and to the maintenance and solutions required for some installations, a lot of qualified and trained installers are required to carry out (execute) this job. In this regard, the CSERS and the Renewable Energy Authority of Libya (REAOL) have to take the responsibility to prepare the programs for training and carry them out to qualify installer (sizing, plumbing, installing, finding solutions) all over Libya. Besides the role of installation, the certified installer has also the role of making sure that the systems

granted subsidy are installed and they have to issue certificate of installation to be used for the subsidy program.

\section{CONCLUSION}

The current study has attempted to suggest a strategic plan for wide spreading 
the use of solar water heaters in the residential sector of Libya. The plan is based on feasibility study of solar water heaters in Libya, and including installation scheme, financing scheme, testing and certification, manufacturing, research and development, and training in accordance with the Libyan social and economic parameters.

The study has found that the estimated technical potential of solar water heaters in Libya is over 2.3 million square meters of solar collectors. The installation scheme suggested in this study is to equip 250,000 homes with solar water heaters by 2022 as 10 year plan started in 2013. A 750 Libyan Dinars is suggested as a subsidy given by the government for each solar system installed according to the scheme, and the money for the program will be obtained from the savings of subsidy used for electricity that would otherwise be used for water heating in the residential sector.

The study has shown also that by completing this program, every Libyan Dinar paid by the government as an incentive will return with 2 time after the completion of the program.

Finally, the study has also asserted the importance of testing, certification, training and research and development related to the solar water heaters complete strategic plan.

\section{ACKNOWLEDGMENT}

The authors would like to thank Dr. Khairy Agha for his valuable comments.

\section{REFERENCES}

[1]- Abdunnabi, M. and Berwian B, Economic and environmental benefits of the replacement of
Solar water heaters instead of electric heaters in Libya, Scientific Journal of Science, Vol(13), July 2005.

[2]-Rafik MISSAOUI, Solar water heater market transformation program in Tunisia, REAOL workshop, 23Jul2009, Tripoli.

[3]- M. Abdurrahman, F. Siala, Planning for Development of Solar Energy in Libya, 16th Global Energy Congress, Tokyo, 1995.

[4]- Annual report, General Electric Company of Libya (GECOL) 2009.

[5]- Khlat, M., Azgalah A., and Madhon, M., Support general electric network of Libya by covering hot water load in the residential sector with solar water heaters, GECOL, internal report.

[6]- Abdunnabi, M. and Loveday, DL., 2010, In -Situ Measurements of the Performance of Thermosyphon Solar Water Heating Systems in Libya, ICRE 2010, 5-8/4/2010, Syria.

[7]- REN21, Renewable Global Status Report, Update 2009.

[8]- I.R. Pillai, and R. Banerjee, 2007, Methodology for estimation of potential for solar water heating in a target area, Solar Energy, 81 (2007) $162-172$.

[9]- B. Batidzirai, E.H. Lysen, S. van Egmond, and W.G. van Sark, 2009, Potential of solar water heating in Zimbabwe, Renewable \& Sustainable Energy Reviews, 13, 567-582.

[10]-K. Gillingham, 2009, Economic efficiency of solar hot water policy in New Zealand, Energy Policy, 37, 3336-3347.

[11]-C.M., Liedl, W.D. Lubitz, 2009, comparing domestic water heating technology, Technology in society, 21, 244-256.

[12]-Statistics Book, 2007, General Authority for Information, Tripoli-Libya.

[13]-Personal contacts, Planning Department, General Electric Company of Libya. 